Phytochemical Studies of ...

\title{
Review Article \\ Phytochemical Studies of Taxus Species and Their Uses in Cancer Treatment
}

\author{
Thaneshwar Subedi \\ Tribhuvan University \\ P.N. Campus, Pokhara, Nepal \\ E-mail: thaneshworsubedi@gmail.com
}

\begin{abstract}
Cancer occurs when cell division runs amok. Cancer is a mass of abnormal, unhealthy cells that are dividing and growing in an uncontrolled way. Cancerous cells with oncogene and damaged deoxyribo nuclic acid (DNA) neither repair nor die. Chemical carcinogens, ionizing radiations, viral or bacterial infection, hormonal change, heredity etc are the main cancer causing agents. In this article, treatment of cancer by plant alkaloid, Taxol, is studied by using secondary sources. Cancer can be treated by plant alkaloids; Taxol, vica rosea, colchicine known as anticancer drugs. Paclitaxel binds the protein tubulin in mitotic spindle, suppresses the tubulin-microtubule dynamic equilibrium, kills the DNA damaged defective cells to control abnormal rapid cell division. Paclitaxel ( $\mathrm{C}_{47} \mathrm{H}_{51} \mathrm{NO}_{14}$ ) has a large number of common, infrequent and rare side effects. Its structure was elucidated and published on the basis of $H^{1}-N M R$ spectrum.
\end{abstract}

Keywords: Cancer, DNA, microtubel, oncogenes, taxol, taxus species, tubulen

\section{Introduction}

The body is made up of trillions of living cells. Under normal conditions, the cells in our body grow, divide and die in an ordinary controlled way. This process is tightly regulated and is controlled by DNA machinery 
Janapriya Journal of Interdisciplinary Studies, Vol. 6 (December 2017)

within the cell. In our body normal cells divide rapidly to allow growth. After the person becomes an adult, most cells divide only to replace wornout or dying cells or to repair injured cells. Cancer cells are different from normal cells because they are not able to control their own growth. When cells of the body of particular site start to grow out of control, they may become cancerous. Instead of dying, cancer cells continue to grow and form new abnormal cells. These cells (tumor) can also invade surrounding healthy body tissue. Such type of tumor is known as malignant tumor. A malignant tumor can spread from its original site to other parts of the body if not found and treated early. This is the property that normal cells do not possess. Cancer is originated from normal cells when their DNA or blue prints within a cell nucleus is damaged. DNA is present in every cell $\&$ it directs all the cells' action, growth, death, protein synthesis etc. When DNA is damaged in a normal cell, the cell either repairs the damage or it dies. In cancer cells, the damaged DNA is neither repaired nor dies. Instead, it gives rise to more such abnormal cells which have the same detective DNA of the original cancer cell.

\section{History of Cancer}

Cancer begins when cells on a part of the body start to grow out of control. All types of cancer start because of uncontrolled growth of abnormal cells. The cancer was discovered in Egypt (although the word cancer was not used) and dates back to about 3000 BC. Greek physician Hippocrates, (460$370 \mathrm{BC})$ who is considered as the "Father of medicine", used the words Carcinos and carcinoma to describe non-ulcer forming and ulcer forming tumors. In Greek, these words refer to a Carb (finger like spreading projections) whose meaning is cancer in Latin word given by Celsius (2850 BC). For this, Galen (130-200 AD) used the word oncos (Greek: swelling). Several theories such as Homoral Theory, Lymph Theory, Blastema Theory, and Infectious Disease Theory were developed up to 1779 to explain cancer. In 1968 Peyton Rous was awarded by Nobel Prize for his description of a type of cancer (sarcoma) in chickens in 1911 at the Rockefeller Institute, New York. In 1960 American Cancer society (ACS) 
Phytochemical Studies of ...

was established to study it. In the early in the $20^{\text {th }}$ century, Adjuvant Therapy (chemo after surgery) was developed. Until 1990s chemotherapy drugs were used to cure cancer. These drugs kill the normal cells but have a greater effect on cancer cells. Now a days,"Targeted Therapy" process is used which controls growth, division and spread of cancer cells, as well as the signals that cause cancer cells to die naturally.

\section{History of Taxol Cancer Treatment}

The first known compound which binds to tubulin was colchicines, Colchicum atumnale, but it has not been used in cancer treatment. The first anticancer drugs approved for clinical use were Vinca alkaloids, Vinblastine and Vincristine, in the 1960s. They were isolated from leaves of the cantharanthus roseus (Vinca rosea) plants in the University of Western Ontario in 1958. In 1962, sample of Pacific yew's bark were first collected by the researchers from US department of Agriculture (USDA) to find natural product that might cure cancer. In 1964 and 1965, additional samples of bark were collected to isolate paclitaxol and its biological action. First drug, along the taxanes and paclitaxel, was discovered in extracts from the bark of the Yew tree, Taxus brevifolia, in 1967 by Monrie Wall and Mansukh Wani but its tubulin (tumor) inhibition activity was not known until 1979. Yews are poor source of active agents which limited the development of taxanes for over 20 years until discover of the way of synthesis (Jordan, 2012). In 1977, the trade name of paclitaxel was also known by "Taxol". In December 1992, paclitaxel was approved to be used in chemotherapy (Gordoliza, 2008).

In 1984, and 1994 the FDA (Food and Drug Administrated) approved taxol for use against ovarian cancer and breast cancer respectively. In 1992 USDA isolated pachitaxel from Taxus brevifolia and structure was reported. In 2003 antitumor and antiangiogenic activity of paclitaxel was reported by Schmidt-Sody. 
Janapriya Journal of Interdisciplinary Studies, Vol. 6 (December 2017)

\section{Paclitaxel}

Paclitaxel (trade name: Taxol) is an anticancer/antitumor chemotherapy drug. It acts as an antineoplastic or cytotoxic drug. It is used for treating various types of cancer including ovarian cancer, breast cancer, non-small cell lung cancer, head and neck, bladder, esophagus cancers, AIDS related Kaposis sarcoma cancer of uterus, prostate, testes (Rowinsky, 1997). Sometimes, it is combined with other anticancer drugs to form a drug Abraxane or nab-paclitaxel used to treat spread breast cancer and pancreatic cancer.

\section{Tubulin}

Tubulun is a "heterodimer" protein in living cell and made from $\alpha$-and $\beta$ tubulin. Tubulin polymerizes into microtubules which may be long chains, filament, hollow' fibers (Microtubule is a polymer of tubulin). Microtubules are one of the major components of the cytoskeleton and function in many processes including structural support, intercellular transport and DNA segregation. The tubulin super family contain six families of tubulins; $\alpha, \beta$, $\Upsilon, \delta, \mathcal{\varepsilon}$ (epsilon) and $\xi$ (Zeta) tubulin (Scholey,2003).

\section{Data and Methods}

In this study, the cancer and paclitaxel related materials, books, research articles, research reports available in library, related research organization, and information from electronic media were collected. These documents which were related to present topic were selected and then studied in detail. Related consultants and patients were also visited to include their suggestions and experience and then these were systematized in the research article.

\section{Results and Discussion}

\section{Mechanism of Formation of Cancer and Treatment by Taxol}

Cancer is a mass of unhealthy cells that are dividing and growing fast and in an uncontrolled way. Oncogenes are formed by changes or mutations of certain normal genes of the cell. These genes cause cells to grow out of 
Phytochemical Studies of ...

control and become cancer cells. These cancerous cells with oncogene or damaged DNA neither repair nor die. Instead they form more abnormal cells with damaged abnormal DNA. All these new cells have the same defective DNA of the original cancer cell. The rate of growth of cancer cell increases with increasing dynamics of tubulin and microtubule.

\section{Figure 1}

Formation of tubulin and Tubulin microtubule equilibrium
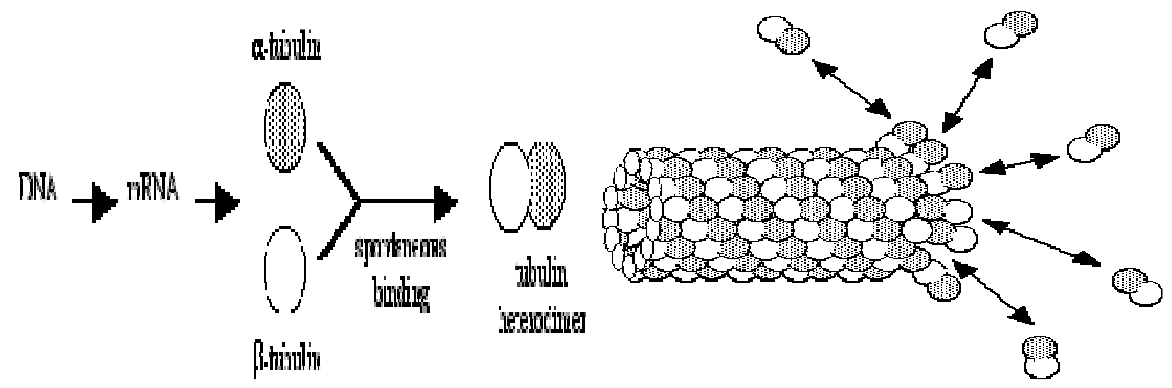

Figure 2: Structure of microtubule
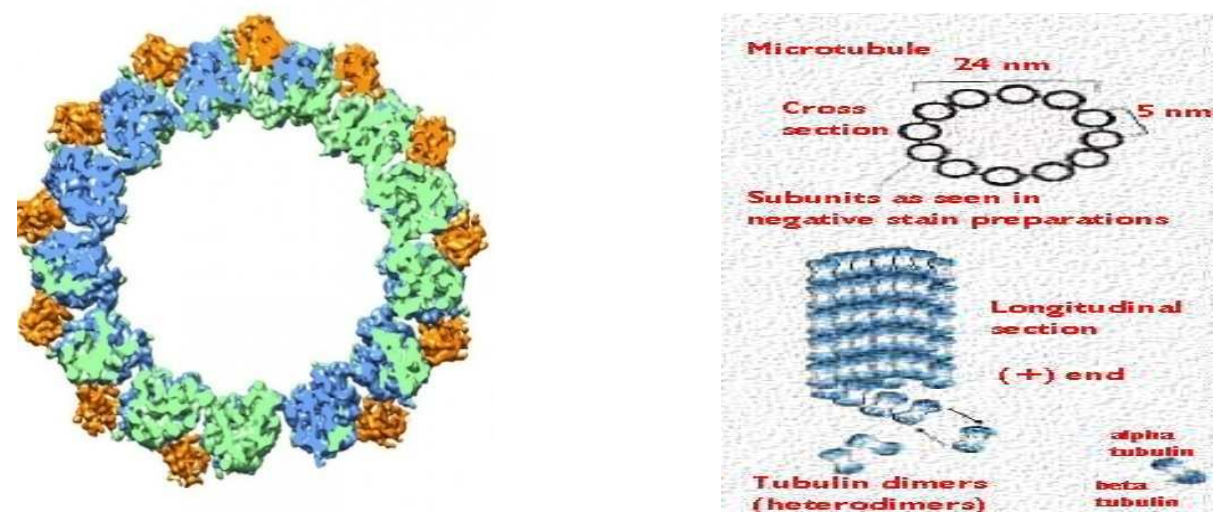

Source: Adapted from Caprette (2012)

\section{Causes of Cancer}

There may be a large number of factors that may cause cancer and it is difficult to pin point an exact cause. Cancer causing agents include: Chemical carcinogens (chemicals and environmental toxins), ionizing 
Janapriya Journal of Interdisciplinary Studies, Vol. 6 (December 2017)

radiations (uv-rays), viral and bacterial infections [HIV, HBV (Hepatitis B Virus), HCV, HPV (Human Pabulum Virus)], genetic or inherited causes, harmonal change and immune system dysturction (Stewart, 2017).

\section{Structure and Anticancer Action of Taxol}

Taxol, a plant alkaloid, is an anti-cancer chemotherapy drug. Chemical name of Taxol (trade name) is paclitaxel, a natural product with anti tumor activity. Paclitaxel is obtained via semisynthetic process from Taxus contorta, Taxus wallichiana, Taxus baccata, Taxus brevifolia. Paclitaxel is white to off-white crystalline powder with the empirical formula $\mathrm{C}_{47} \mathrm{H}_{51} \mathrm{NO}_{14}$ and molecular weight 853.9. It is highly lipophilic, insoluble in water and melt at around $216-217{ }^{\circ} \mathrm{C}$. The chemical name for paclitaxel is $5 \beta, 20$-Epoxy-1, 2 $\alpha, 4,7 \beta, 10 \beta, 13 \alpha$-hexahydroxy tax-11-en-9-one 4, 10 diacetate 2-benzoate13esterwith(2R,3S)-N-benzoyl-3-phenylisoserine (http://www.drugs.com/pro/taxo.html.). Paclitaxel has the following structural formula. The structure was reported by USDA in 1992.

Figure 2

Structure of Taxol

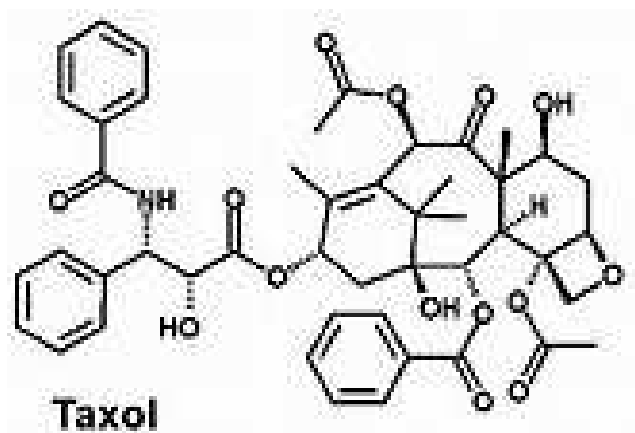

Source: Adapted from Farjon, 2017

Agents which act as inhibitors of tubulin also act as inhibitor of cell division as well as anticancer drug. Microtubule exists in a continuous dynamic state of growing (polymerization) and shortening (depolymerisation) by reversible association and dissociation of $\alpha / \beta$ tubulin heterodimers at both the ends. Tubulin inhibitors act by interfering 
Phytochemical Studies of ...

with the dynamics of microtubule. Paclitaxel is depolymerisation inhibitor (inhibit the deploymerisation of microtubule into tubulin) or microtubule stabilizing agent. Vinca alkaloids (Vinbalstine and vincristine) and colchicines analogues are polymerization inhibitor (inhibit the polymerization of tubule into microtubules) or microtubule destabilizing agent. Microtubule polymerized in presence of paclitaxel is extremely stable and it reduces the critical tubulin sub-unit concentration. This process controls the division of abnormal cell with defective DNA. If the cells are unable to divide, they die causing the tumor to shrink. Thus the suppression of microtubule dynamics is the main cause of the inhibition of cell division and the tumor cell death in paclitaxel treated cells. Paclitaxel attack the cells during various phases of division.

Colchicine binds to the $\beta$-subunit of soluble-tubulin complex. This complex polymerises with normal tubulin to form microtubule with T-C complex which prevents the further polymerization of microtubule. Vinca alkaloids bind to $\beta$-subunit of tubulin rapidly with low affinity and microtubule with high affinity and prevent the further polymerization of microtubule (Jordan, 2012).

\section{Side Effects of Taxol}

Chemotherapy is most effective for killing tumor cells that are rapidly dividing. Unfortunately, chemotherapy does not know the difference between the cancerous cells and the normal cells. The normal cells will grow back and become healthy but in the meantime, side effect occurs. The normal cells most commonly affected by chemotherapy are blood cells, cells in the mouth, stomach \& bowel and hair follicells.

Paclitaxel has interaction with a large number of medicines. A total of 353 drugs (1172 brand and genetic names) are known to interact with paclitaxel. Of them 48 are major, 298 are mordate and 7 are minor drug interactions. Using paclitaxel and Daltopristin, Epirubicin, Fosphenytoin, Lapatinilo, phynytoin, Quinupristin may increase risk of certain side effects. It has interactions with certain type of foods, tobacco and alcohols.

The presence of medical problems like Bardycardia (slow hearth rate), Heart Rhythm Problem, Hypertension (high blood pressure), Hypotension 
Janapriya Journal of Interdisciplinary Studies, Vol. 6 (December 2017)

(low blood pressure), Peripheral Neuropathy may affect the use of this medicine. Paclitaxel may cause unwanted side effects that require medical attention.

\section{Table 1}

\section{Side Effects of Taxol Intravenous}

\begin{tabular}{|c|c|c|}
\hline Common & Infrequent & Rare \\
\hline $\begin{array}{ll}\text { - } & \text { Anemia, Hair loss } \\
\text { - } & \text { Decreased blood } \\
\text { - } & \text { pressure } \\
\text { - } & \text { Joint pain } \\
\text { - } & \text { Decreased neutrophils } \\
\text { - } & \text { Muscle pain } \\
& \text { Decreased white blood } \\
\text { cells Numbness \& } \\
\text { - } & \text { Tingling } \\
\text { - } & \text { Rash } \\
\text { - } & \text { Pain of hands \& feet } \\
\text { - } & \text { Throwing of skin } \\
\text { - } & \text { Breathing trouble } \\
\text { - } & \text { Visible water retention } \\
\text { - } & \text { Diarrhea }\end{array}$ & $\begin{array}{ll}\text { - } & \begin{array}{l}\text { Abnormal liver } \\
\text { function tests }\end{array} \\
\text { - } & \text { Abnormally low } \\
\text { blood pressure } \\
\text { - } & \text { Allergic reaction } \\
\text { caused by a drug } \\
\text { - } & \text { Giant hives } \\
\text { - } & \text { Hives } \\
\text { - } & \text { Life threatening } \\
\text { - } & \text { allergic reaction } \\
& \text { Severely decreased } \\
\text { level of nutrophils in } \\
\text { the blood } \\
\text { Slow hears beat. }\end{array}$ & $\begin{array}{ll}\text { - } & \text { Ascites } \\
\text { - } & \text { Dead skin } \\
\text { - } & \text { Extreme loss of body } \\
\text { - } & \text { High blood pressure } \\
\text { - } & \text { Hole in the intestine } \\
\text { - } & \text { Insufficient blood supply } \\
\text { - } & \text { Painful, red or swollen } \\
\text { - } & \text { Pancreatitis } \\
\text { - } & \text { Paralysis of the intestine } \\
\text { - } & \text { Stomacher intestine } \\
\text { - } & \text { blockage } \\
\text { - } & \text { weakness } \\
\text { - } & \text { Fibrous thickening of } \\
\text { - } & \text { Incomplete or infrequent } \\
\text { - } & \text { bowel moments, } \\
\text { Itching }\end{array}$ \\
\hline
\end{tabular}

Source: www.drugs.com/sfx/taxol-side-effects.html (Assessed on August $12,2017)$

The main taxus species from which paclitaxel is extracted are Taxus contorta, Taxus baccata, Taxus brevifolia and Taxus Wallichiana. Taxonomy of these species is given below. 
Phytochemical Studies of ...

Figure 3: Figure showing the different species of taxus

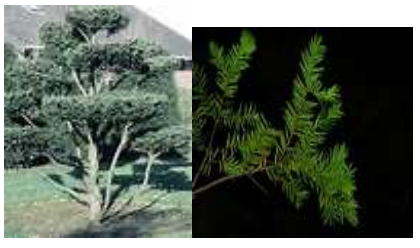

Taxus Contorta

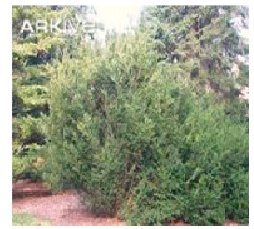

Taxus

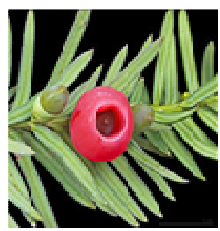

Taxus baccata

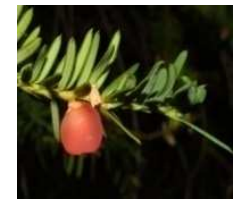

Taxus Brevifoli Wallichiana

\section{Table 2}

Table showing the detail information on different types of species of taxus

\begin{tabular}{|c|c|c|c|}
\hline Taxus Contorta & Taxus Wallichiana & Taxus baccata & Taxus Brevifoli \\
\hline Kingdom:Plantae, & Kingdom: Plantae & Kingdom : Planta & Kingdom : Plantae, \\
\hline Tracheophyta & Tracheophyta & hyta & Tra \\
\hline Class: Pinopsida, & Class: Pinopsida & Class: Pinopsida & Pinopsida, \\
\hline Order: Pinales & Order: & Order: Pinales & Pinales \\
\hline Family:Taxaceae, & Family:Taxaceae & Family: Taxacea & Family: Taxaceae \\
\hline Genus: Taxus & Genus : Taxus & Genus: Taxus & Genus: Taxus \\
\hline $\begin{array}{l}\text { Species: } \quad \mathrm{T} \text {. } \\
\text { contorta, }\end{array}$ & $\begin{array}{l}\text { Species: } \\
\text { Wallichiana }\end{array}$ & $\begin{array}{l}\text { Species : T. baccata } \\
\text { Scientific name: }\end{array}$ & $\begin{array}{l}\text { Species : } \\
\text { Brevifolia }\end{array}$ \\
\hline Scientific & Scientific & Taxus baccata & Scientific \\
\hline Taxus contorta & Taxus Wallichiana & Common & Taxus Brevifolia \\
\hline Common & Common name & Common & Common \\
\hline $\begin{array}{l}\text { West Himalayan } \\
\text { Yew }\end{array}$ & $\begin{array}{l}\text { East Himalayan yew, } \\
\text { Himalayan yew }\end{array}$ & $\begin{array}{l}\text { European } \\
\text { English yew }\end{array}$ & $\begin{array}{l}\text { Pacific Yew, } \\
\text { Canadian Yew }\end{array}$ \\
\hline
\end{tabular}

Sources:http://www.worldbotanical.com/images/ARS\%20NCI\%20Active \%20Plants/21_Spjut_TaxonomyTaxus_203-289Web.pdf.

http://www.worldbotanical.com/images/ARS\%20NCI\%20Active\%20Plant s/21_Spjut_Taxon

omy Taxus_203-289Web.pdf

http://www.worldbotanical.com/images/ARS\%20NCI\%20Active\%20Plant s/21_Spjut_Taxon

omyTaxus_203-289Web.pdf

Geographic range: Himalayan yew occurs in Afghanistan, Pakistan, Northwestern India and Central \& Western Nepal. Its lower elevation limit 
Janapriya Journal of Interdisciplinary Studies, Vol. 6 (December 2017)

is 1700 metres and higher elevation limit 3100 meters. It generation length is 30 years.

Medical uses: Bark, leaves and twigs have a traditional medical uses and are also used for commercial production of 'Taxol', an anti-cancer drug.

Geographic range: This species is found in China (Tibe), East Nepal, Bhutan, India, Myanmar, Vietnam, Malaysia, Philippines, and North east Thailand. Its lower and higher elevation limit is 900 metres and 3700 metres. Its generation length is 30 years.

Medical uses: It has medical uses in Ayurveda and Tibetan medicine. Taxus Wallichina is used for making Tea by the Bhotya tribal community in the Garhwal Himalaya. The alkaloid compound of the bark and leaves (in low concentration) are the source of anticancer drug paclitaxel (Taxol) (Medical, 2009). Young shoots, leaves, inner bark are also used for traditional medicine. Inner bark is also used as red dye in religious ceremonies by Brahmins of Nepal (Thomas, 2011).

Geographic range: This species is found in southwest Asia, western, central and southern Europe, Northwest Africa, and Northernn Iran. This small to medium-sized evergreen slow growing tree is poisonous. Its lower elevation limit is 1 meters and upper elevation limit is 2500 meters.

Medical uses: The taxol obtained from the bark of this tree is used for treatment of breast and ovarian cancer in the central Himalayas (IUCN, 2006).

Geographic range: It occurs in Southeast Alaska (California), eastern Washington and Oregon, Pacific Coast of northern California. This Shrub variety tree grows from 1000-1219 meters.

Medical uses: The bark of the tree held the compound 'Taxol' that inhibits the growth of various cancerous tumors. 
Phytochemical Studies of ...

\section{Conclusion}

Tumor, a group of cancerous cell, is formed due to increasing dynamic equilibrium of tubulin-microtubulin within a cell with damaged DNA. The main factors that may cause cancer are chemical carcinogenes, ionizing radiations, viral or bacterial infection, harmonal change and genetic causes. Paclitaxel (Taxol), a plant alkaloid, extracted from taxus species : 'Taxus contorta', 'Taxus wallichiana', 'Taxus brevifolia' and 'Taxus baccata', is used as anticancer drug for treating various cancer. Paclitaxel is whitish crystalline powder with the empirical formula $\mathrm{C}_{47} \mathrm{H}_{51} \mathrm{NO}_{14}$ and molecular weight 853.9. It melts around $216-217^{\circ} \mathrm{C}$. Paclitaxel suppresses the dynamic equilibrium of tubulin and microtubule to halt the rapid cell division by binding mitotic spindle within a cell. It attacks the cell with damaged DNA in various stages of cell division and causes death of DNA damaged abnormal detective cells. Although, paclitaxel is used as most effective anticancer drug, its use causes large number of unwanted common, infrequent and rare side effects.

\section{References}

Bhattarai, N. K., \& Karki, N. B. (2004). Conservation and management of Himalayan medical plants in Nepal. http://lib.icimod.org/record/ 20326 (retrieved on August 23, 2017) .

Cardinal, C, \& Yarbno, J. A. (1979). Conceptual history of cancer. Semin Oncol, 6, 396-408.

Caprette, D.R. (2012). Experimental Biosciences Resources. Rice University.

Contran, R., Kumar, V., \&Robbins, S. (1989). Robbins pathologic basis of disease $\left(4^{\text {th }}\right.$ ed). Philadelphia, Pa: WB Saunders.

Dordaliza, M. (2008). Natural products as leads to anticancer drugs. Clinical and Translational Oncology. 9(12), 767-76.

E. M., Donoghue, G. L., Benson. J. L., \& Chambenlain (2003). Sustainable production of wood and non-wood, forest product, Proceeding of IUFRO Division 5 Research Groups 5-11 and 5-12, Rotorua. New Zeland. 
Janapriya Journal of Interdisciplinary Studies, Vol. 6 (December 2017)

Farjon, A. (2017). A Handbook of world's conifers. https://books.google.com/books?isbn=9004324429 (retrieved on September 12, 2017).

Farjon. A. (2013). Taxus baccata. The IUCN Red List of Threatened species 2013.e.T42546A29866660. Retrieved from: http:dx.doi.org/10.2305/IUCN.UK.20131.RLTS.T42546A296160.en

Daniel, G., Farncoise, G. V, \& Potier, P. (1993). Taxol and taxotere: Discovery, chemistry and structure- activity relationships. Acc.Chem.Res, 26, 160-167.

IUCN. (2011). IUCN Red List of Threatened species (Ver-2011.2). Available at : http/www.IUCNredlist.org (retrieved on July 16, 2017)

Jordan, M. (2012). Mechanism of Action of Antitumor Drugs that Interact with Microtubules \& Tublin. Current Medical Chemistry- AntiCancer Agents. 2(1), 1-17.

Kamal, M. (2016, August 20). Kaudiko bhauma cancerko aausadhi. Annapurna Post,

Scholey, J. M. (2003). Intraflagellar tansport. Annu Rev cell Dev Biol, 19, 423-443.

Spjut., R. W. (2007). Taxonomy and nomenclature of Taxus (Taxaceae). Journal of the Botanical Research Institute of Texas, 1(1), 203-289,

Stewart, M. (2017). Cause of cancer. Accessed from wikipedia.org/wiki/ Causes of cancer.

Thomas, P. (2011). Taxus contorta. The IUCN Red List of Threatened species 2001: et39147A10170545, Retrieved from http://dx.doi.org/ 10.2305/IUCN.UK.2011-2.RLTS. T39147A10170545.en

Thomas, P., \& Farjon, A. (2011). Taxus wallichiana. The IUCN Red List of Threatened species 2011. 